\title{
Fabrication of Dual Layer Hollow Fibre Membranes for Photocatalytic Degradation of Organic Pollutants
}

\author{
Hazlini Dzinun, Mohd Hafiz Dzarfan Othman, A. F. Ismail, Mohd Hafiz Puteh, Mukhlis A. Rahman, \\ and Juhana Jaafar
}

\begin{abstract}
In recent years, the membrane photocatalytic reactor (MPR) systems have attracted much attention due to their promising function in treating organic pollutant and filtering clean water. Suspended photocatalyst titanium dioxide $\left(\mathrm{TiO}_{2}\right)$ particle always become a problematic in hybrid MPR system due to membrane fouling and $\mathrm{TiO}_{2}$ loss. In the past few years, considerable attention has been paid to immobilize $\mathrm{TiO}_{2}$ nanoparticles on various materials. Since ultraviolet (UV) source and $\mathrm{TiO}_{2}$ are required for the photocatalytic reaction, thus, it is crucial to immobilize high concentration of $\mathrm{TiO}_{2}$ on the outer surface of the polymeric membrane support. By using co-extrusion approach, a dual layer hollow fibre (DLHF) membrane was fabricated. The effect of additives on the dope polymer solutions and membrane morphologies of DLHF were investigated using of scanning electron microscopy (SEM). The SEM results showed that DLHF membranes have a good adhesion between layers with no delamination.
\end{abstract}

Index Terms-Dual-layer hollow fibre membrane, co-extrusion, photocatalytic degradation, Titanium dioxide.

\section{INTRODUCTION}

Several studies have showed difficulties in degrading some organic pollutants in wastewater using conventional biodegradation technique [1]. Fortunately, the degradation and mineralization of the pollutant are possible to be achieved by the application of advanced technologies such as photocatalytic oxidation [2], [3]. Photocatalysis, based on the generation of hydroxyl radicals $(\mathrm{OH})$ is considered as a promising approach for removal of organic pollutants. Organic pollutants can be degraded up to $90 \%$ under operation by using suspended catalyst which commonly is titanium dioxide $\left(\mathrm{TiO}_{2}\right)$ nanoparticles due to its remarkable charge transport property and superior oxidation ability [4]. Unfortunately, the suspended catalyst reactor needs the additional process in order to separate catalyst from the treated water after the degradation. A number of researchers have suggested photocatalyst immobilization onto a suitable solid support. Even though this approach would eliminate the

Manuscript received September 2, 2014; revised November 22, 2014 This work was financially and technically supported by the European Commission FP7 - LIMPID (Project number: NMP3-SL-2012-310177), Sciencefund (Project Number: R.J130000.7942.4S033), Exploratory Research Grant Scheme (Project Number: R.J130000.7842.4L104) and Research Management Centre, Universiti Teknologi Malaysia.

Hazlini Dzinun, Mohd Hafiz Dzarfan Othman, A. F. Ismail, Mukhlis A. Rahman, and Juhana Jaafar are with the Advanced Membrane Technology Research Centre (AMTEC), Universiti Teknologi Malaysia, 81310 Skudai, Johor, Malaysia (e-mail: hazlini4@live.utm.my, hafiz@petroleum.utm.my, afauzi@utm.my, mukhlis@petroleum.utm.my,juhana@petroleum.utm.my).

Mohd Hafiz Puteh is with the Department of Environmental Engineering, Universiti Teknologi Malaysia, 81310 Skudai, Johor, Malaysia (e-mail: mhafizputeh@utm.my). need of post-treatment process, but it would reduce the surface area available for photocatalytic reaction [5], [6]. Most of studies reported the same results which was the suspended catalyst give better degradation than catalyst deposited on the membrane [7]-[9]. Some other inherent problems create by immobilization of the photocatalyst are potential loss of $\mathrm{TiO}_{2}$ and decreased adsorption of organic substances on the $\mathrm{TiO}_{2}$ surface during long-time use [10].

However, the photocatalyst immobilization within polymeric membrane still has some specific practical advantages: (i) the catalyst is embedded into the membrane without any covalent bond formation, thus avoiding its chemical modification. (ii) polymeric membranes show different affinities for different chemicals, therefore, the adsorption and the diffusion of the reactants can be modulated, (iii) the photocatalytic degradation process may be performed in a system in which reaction and separation processes occur simultaneous. (iv) finally, all advantages of true membrane processes, such as modularity, design, and easy scale-up, may be attained [11].

Early development of photocatalytic membranes has been focused on flat sheet membranes made from polyacrylonitrile (PAN) and quite stable to UV light over a $24 \mathrm{~h}$ period of irradiation [12]. In contrary, Chin et al., in 2006 found out that PAN membrane is not suitable to be exposed to 10 days of $200 \mathrm{mM} \mathrm{H}_{2} \mathrm{O}_{2} / \mathrm{UV}$ condition and revealed that polytetraflouroethylene (PTFE) and hydrophobic polyvinylidenefluoride (PVDF) are the better choice for photocatalytic applications [13].

To date, many researchers attracted to fabricate dual layer hollow fibre membranes via a single-step co-extrusion technique due to its advantages such as low material cost, less complex post treatment process and better membrane performance. However, it is very challenging to produce high performance dual layer hollow fiber membranes because it involves a sophisticated spinning process where two different phase inversion pathways occur simultaneously. The major problem in dual layer hollow fibre membranes is low integrity and delamination problem. A good adhesion between inner and outer polymers dope can only be achieved by properly control the spinning parameters such as bore fluid composition, spinning process temperature, air gap height [14] and ratio of outer layer dope flow rate to inner dope flow rate [15].

To our best knowledge, the degradation of organic pollutants by using photocatalytic dual layer hollow fibre membranes has not been reported. Therefore, the development of a novel dual layer hollow fibre membrane, as shown in Fig. 1, for photocatalytic system was carried out in this study. The effect of additives such as polyethylene glycol 
(PEG), titanium dioxide $\left(\mathrm{TiO}_{2}\right)$, ethanol and methanol on the dope viscosity and membrane morphology was examined.

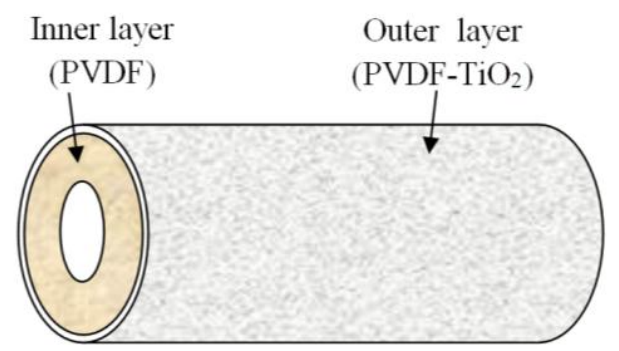

Fig. 1. PVDF-TiO $2 / \mathrm{PVDF}$ dual layer hollow fiber membrane.

\section{PROCEDURE}

\section{A. Materials}

PVDF (Polyvinylidene flouride, Solef 6000 Series powder, Solvay Specialty Polymers France) was used as polymer based without purification. $\mathrm{TiO}_{2}$ nanoparticles was supply by Johnson Matthey, UK. PEG, methanol and ethanol (analytical grade) were purchased from Fluka. DMAC (Dimethylacetamide, Sigma Aldrich) was used as solvent to dissolve polymer without further purification.

\section{B. Preparation of Dope Solution}

The PVDF and $\mathrm{TiO}_{2}$ nanoparticles were dried in a $50^{\circ} \mathrm{C}$ vacuum oven for 24 hour before they were used for dope preparation. Spinning solutions were prepared by addition of the $\mathrm{TiO}_{2}$ nanoparticles to the DMAc solvent in Scott bottle with an overhead stirrer. Table I lists the composition of both inner and outer layers of the membrane.

TABLE I: DIFFERENT DOPE COMPOSITION OF POLYMER MEMBRANES

\begin{tabular}{|c|c|}
\hline Parameters & Values \\
\hline Outer dope flow rate $(\mathrm{ml} / \mathrm{min})$ & 1 \\
\hline Inner dope flow rate $(\mathrm{ml} / \mathrm{min})$ & 8 \\
\hline Bore fluid & Distilled water \\
\hline Bore fluid flow rate $(\mathrm{ml} / \mathrm{min})$ & 8 \\
\hline Air gap $(\mathrm{cm})$ & 10 \\
\hline Take up speed $(\mathrm{m} / \mathrm{s})$ & 0.18 \\
\hline Aging time & 1 day in water \\
\hline Post treatment & $\begin{array}{l}\text { 1. Immersion of hollow fibre in } \\
\text { (ethanol: water, } 50: 50 \text { wt. } \% \text { ) for } \\
1 \text { hours, then } 100 \% \text { of ethanol for } \\
1 \text { hours in order to improve the } \\
\text { membrane wettability and pore } \\
\text { collapse [16]. } \\
\text { 2. Drying of hollow fibre at room } \\
\text { temperature for } 3 \text { days before } \\
\text { module fabrication. }\end{array}$ \\
\hline
\end{tabular}

For preparing the blend dope solutions, the $\mathrm{TiO}_{2}$ nanoparticles were fully dispersed in the solvent by stirring for a period of 12 hour before the polymers were added to the mixture. The prepared solutions were degassed overnight by using ultrasonic bath system at ambient temperature before they were used for spinning.

\section{Spinning of Dual Layer Hollow Fibre}

The prepared spinning dope mixture was extruded using a triple orifice spinneret to form dual layer hollow fibre membranes as stated detail elsewhere [17]. The dimension of the spinneret is shown in Fig. 2.
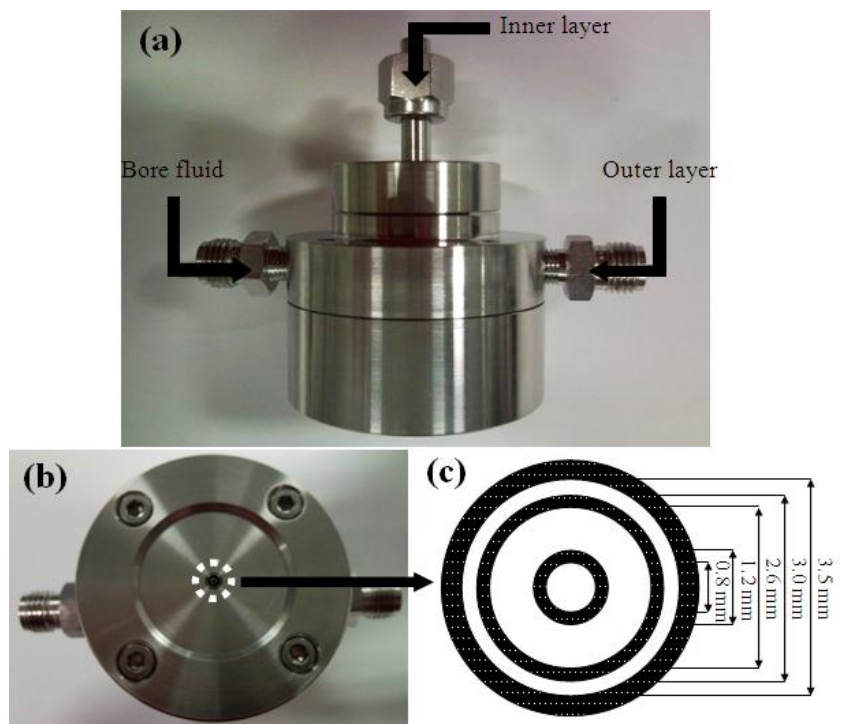

Fig. 2. Photographic images of (a) triple orifice spinneret from side, (b) triple orifice spinneret from bottom, and (c) dimension of the triple orifice spinneret [17].

The spinning conditions that were applied to fabricate the hollow fibre membranes are summarized in Table II.

TABLE II: SPINNING CONDITIONS FOR THE DUAL LAYER HOLLOW FIBRE MEMBRANES

\begin{tabular}{|c|c|c|}
\hline Layer type & Polymer/Additives/Solvent & Composition (wt\%) \\
\hline \multirow{3}{*}{ Inner } & PVDF/DMAc & $18 / 82$ \\
\hline & PVDF/PEG/DMAc & $18 / 5 / 77$ \\
\hline & PVDF/Ethanol/DMAc & $18 / 5 / 77$ \\
\hline \multirow{3}{*}{ Outer } & $\mathrm{PVDF} / \mathrm{PEG} / \mathrm{TiO}_{2} / \mathrm{DMAc}$ & $18 / 5 / 2 / 75$ \\
\hline & $\begin{array}{c}\text { PVDF/ } \\
\text { Methanol/TiO } / \mathrm{TMAc}_{2} / \mathrm{DMA}\end{array}$ & $18 / 5 / 2 / 75$ \\
\hline & $\mathrm{PVDF} / \mathrm{TiO}_{2} / \mathrm{DMAc}$ & $18 / 2 / 80$ \\
\hline
\end{tabular}

\section{Characterization of Dual Layer Hollow Fibre}

Before spinning, the viscosity of prepared solutions was measured using viscometer 20-2 million centPoise (Cole Parmer, Model: EM-98965-40).

The structural morphology of the membrane inner and outer layers was examined qualitatively by scanning electron microscopy (SEM, Model: TM 3000, Hitachi). To prepare the samples, the membranes were immersed in liquid nitrogen for $10 \mathrm{~min}$ and then fractured to reveal their cross sectional morphology. The samples were then positioned on a metal holder and sputter-coated with gold under vacuum for 3 min. Micrographs of their cross sectional and surface morphologies were taken and inspected at various magnifications.

\section{RESULT AND DISCUSSION}

Fig. 3 shows the effect of additives on viscosity of the dope solution, where the viscosity increased with the addition of additives. The high viscosity of dope solution would slow down the mass transfer rate during the membrane formation process and prevent the formation of macroporous structure, consequently improving the membrane mechanical strength. 
However, too high viscosity would result to inconsistent flow and thus affect the production of membrane with desired structure. Based on the viscosity values shown in Fig. 3, two dopes for the inner layer (i.e. PVDF/DMAc and PVDF/ethanol/DMAc) and the outer layer (i.e. $\mathrm{PVDF} / \mathrm{TiO}_{2} / \mathrm{DMAc}$ and $\left.\mathrm{PVDF} / \mathrm{PEG} / \mathrm{TiO}_{2} / \mathrm{DMAc}\right)$ were subjected to the co-spinning of dual layer hollow fibre membranes.

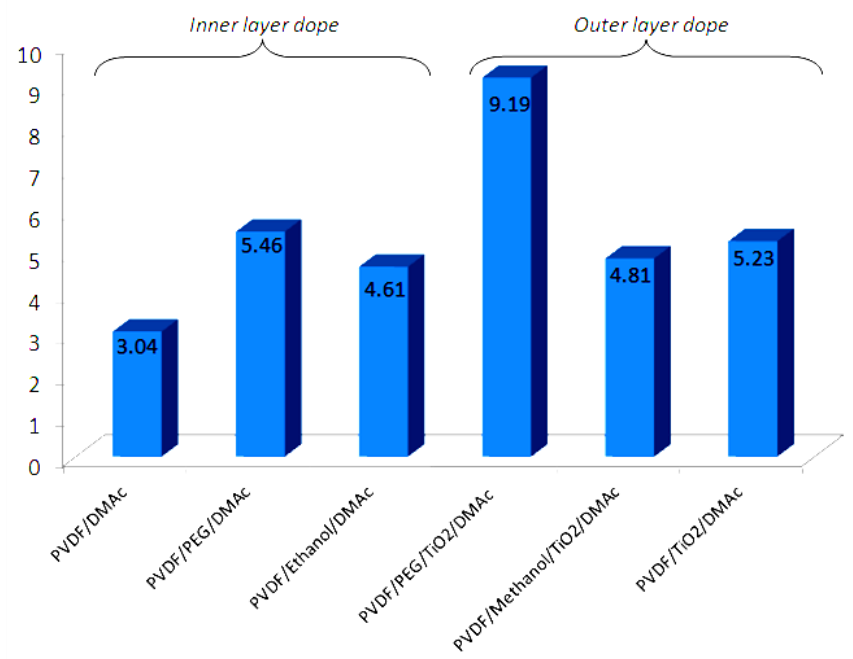

Fig. 3. Effect of additives on viscosity of dope solution.

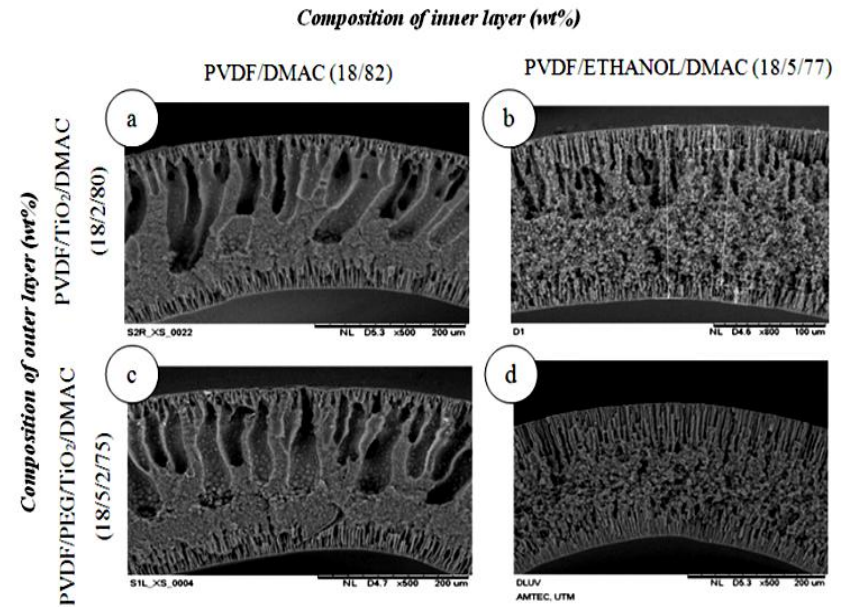

Fig. 4. SEM images of dual layer hollow fibre PVDF membranes with different inner and outer dope composition.

Fig. 4 shows the cross-sectional morphologies of four membranes were spun from different compositions of the outer and inner dope solutions. It can be seen that the finger like void structure formed in the outer layer. When the pore former PEG was added in the outer layer dope, the morphology of finger like structure was adjusted as clearly shown in Fig. 4 (c) compared with Fig. 4 (a).

Ethanol was added in the inner layer dope in order to achieve desired morphology of clear thickness of sponge like structure that could act as separation layer. Based on the Fig. 4 (b), it can be seen that the morphology on the cross section of dual layer hollow fiber spun is sandwich-like structure where finger-like voids formed from the bottom and the top surface of membrane and separated by sponge-like structure at the middle of the membrane cross-section. Ethanol has high mass exchange rate with water at the precipitation front. The water intrusion during coagulation bath was retarded when ethanol was introduced into the inner layer dope [18].

When PEG was introduced in the outer dope solution, the morphology of dual layer hollow fiber membranes remained sandwich structure but the length of finger-like structure increased as shown in Fig. 4 (d). This result is in agreement with the finding reported by [19], where they observed the enlargement of pore size and porosity of membrane. Such structure is expected could enhance pure water flux and reduce solute rejection of membranes [20]. It is also worth to note that all hollow fibre possessed a good adhesion between layers as no delamination could be observed.

\section{CONCLUSION}

Dual layer hollow fibre membranes have successfully fabricated by single step co-extrusion techniques. The obtained dual layer hollow fibre membranes consists of sandwich-like structure where finger-like voids formed from the inner and the outer surface of membrane and separated by sponge-like structure at the middle of the membrane cross-section. The results obtained from the analysis conducted indicate that viscosity of the dope solution have significant effect on phase inversion process and thus, affect the final structure of the hollow fibre membrane.

\section{ACKNOWLEDGMENT}

The authors gratefully acknowledge financial support from the European Commission FP7 - LIMPID (Project number: NMP3-SL-2012-310177), Sciencefund (Project Number: R.J130000.7942.4S033), Exploratory Research Grant Scheme (Project Number: R.J130000.7842.4L104) and technical support from both Aquakimia Sdn. Bhd. and Research Management Centre, Universiti Teknologi Malaysia. The authors also acknowledge Solvay Specialty Polymers Italy and Johnson Matthey PLC UK for providing materials used in this work.

\section{REFERENCES}

[1] I. R. Falconer, H. F. Chapman, M. R. Moore, and G. Ranmuthugala, "Endocrine-disrupting compounds: A review of their challenge to sustainable and safe water supply and water reuse," Environmental Toxicology, vol. 21, no. 2, pp. 181-191, 2006.

[2] M. Ahel, F. E. Scully, J. Hoign, and W. Giger, "Photochemical degradation of nonylphenol and polyethoxylates in natural waters nonylphenol," Chemosphere, vol. 28, no. 7, pp. 1361-1368, 1994.

[3] S. Kohtani, S. Makino, A. Kudo, K. Tokumura, and Y. Ishigaki, "Photocatalytic degradation of 4-n-nonylphenol under irradiation from solar simulator: Comparison between $\mathrm{BiVO}_{4}$ and $\mathrm{TiO}_{2}$ photocatalysts," Chemistry Letters, vol. 31, pp. 660-661, 2002.

[4] Y. Xin, M. Gao, Y. Wang, and D. Ma, "Photoelectrocatalytic degradation of 4-nonylphenol in water with $\mathrm{WO} 3 / \mathrm{TiO} 2$ nanotube array photoelectrodes," Chemical Engineering Journal, vol. 242, pp. 162-169, 2014.

[5] M. N. Chong, B. Jin, C. W. K. Chow, and C. Saint, "Recent developments in photocatalytic water treatment technology: a review," Water Research, vol. 44, no. 10, pp. 2997-3027, 2010.

[6] V. M. Daskalaki, Z. Frontistis, D. Mantzavinos, and A. Katsaounis, "Solar light-induced degradation of bisphenol-A with $\mathrm{TiO}_{2}$ immobilized on Ti," Catalysis Today, vol. 161, no. 1, pp. 110-114, 2011.

[7] H. Jiang, G. Zhang, T. Huang, J. Chen, Q. Wang, and Q. Meng, "Photocatalytic membrane reactor for degradation of acid red B wastewater," Chemical Engineering Journal, vol. 156, no. 3, pp. 571-577, 2010.

[8] S. Kertèsz, J. Cakl, and H. Jiránková, "Submerged hollow fiber microfiltration as a part of hybrid photocatalytic process for dye wastewater treatment," Desalination, vol. 343, pp. 106-112, 2013.

[9] G. Mascolo, R. Comparelli, M. L. Curri, G. Lovecchio, A. Lopez, and A. Agostiano, "Photocatalytic degradation of methyl red by $\mathrm{TiO}_{2}$ : Comparison of the efficiency of immobilized nanoparticles versus 
conventional suspended catalyst," Journal of Hazardous Materials, vol. 142, no. 1-2, pp. 130-137, 2007.

[10] K. V. S. Rao, M. Subrahmanyam, and P. Boule, "Immobilized $\mathrm{TiO}_{2}$ photocatalyst during long-term use: decrease of its activity," Applied Catalysis B: Environmental, vol. 49, no. 4, pp. 239-249, 2004.

[11] M. D. Arienzo, M. Crippa, A. A. Essawy, R. Scotti, L. Wahba, F. Morazzoni, and I. R. Bellobono, "Membrane-assisted charge separation and photocatalytic activity in embedded $\mathrm{TiO}_{2}$ : A kinetic and mechanistic study," The Journal of Physical Chemistry, vol. 114 , no. 37 , pp. 15755-15762, 2010.

[12] R. Molinari, M. Mungari, E. Drioli, A. Di Paola, V. Loddo, L. Palmisano, and M. Schiavello, "Study on a photocatalytic membrane reactor for water purification," Catalysis Today, vol. 55, no. 1-2, pp. 71-78, 2000.

[13] S. S. Chin, K. Chiang, and A. G. Fane, "The stability of polymeric membranes in a $\mathrm{TiO}_{2}$ photocatalysis process," Journal of Membrane Science, vol. 275, no. 1-2, pp. 202-211, 2006

[14] D. Bhandari, K. O. Olanrewaju, N. Bessho, V. Breedveld, and W. J. Koros, "Dual layer hollow fiber sorbents: Concept, fabrication and characterization," Separation and Purification Technology, vol. 104, pp. 68-80, 2013.

[15] D. Li, T. S. Chung, and R. Wang, "Morphological aspects and structure control of dual-layer asymmetric hollow fiber membranes formed by a simultaneous co-extrusion approach," Journal of Membrane Science, vol. 243, no. 1-2, pp. 155-175, 2004.

[16] O. Tahiri, Q. Trong, C. Mbareck, and T. Rhlalou, "Applied Catalysis A : General elaboration and study of poly (vinylidene fluoride )- anatase $\mathrm{TiO}_{2}$ composite membranes in photocatalytic degradation of dyes," Applied Catalyst A: General, vol. 358, pp. 13-20, 2009.

[17] M. H. D. Othman, Z. Wu, N. Droushiotis, U. Doraswami, G. Kelsall, and $\mathrm{K} . \mathrm{Li}$, "Single-step fabrication and characterisations of electrolyte/anode dual-layer hollow fibres for micro-tubular solid oxide fuel cells," Journal of Membrane Science, vol. 351, no. 1-2, pp. 196-204, 2010.

[18] S. P. Sun, K. Y. Wang, N. Peng, T. A. Hatton, and T. S. Chung, "Novel polyamide-imide/cellulose acetate dual-layer hollow fiber membranes for nanofiltration," Journal of Membrane Science, vol. 363, no. 1-2, pp. $232-242,2010$.

[19] H. Song, J. Shao, Y. He, B. Liu, and X. Zhong, "Natural organic matter removal and flux decline with PEG-TiO ${ }_{2}$-doped PVDF membranes by integration of ultrafiltration with photocatalysis," Journal of Membrane Science, vol. 405-406, pp. 48-56, July 2012

[20] D. Zuo, Y. Xu, W. Xu, and H. Zou, "The influence of PEG molecular weight on morphologies and properties of PVDF asymmetric membranes," Chinese Journal of Polymer Science, vol. 26, no. 4, pp. 405-414, 2008.

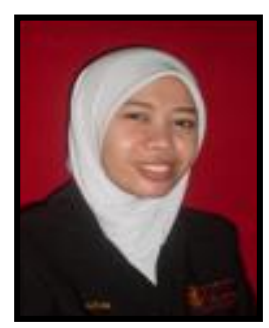

Hazlini Binti Dzinun received her bachelor of chemical engineering degree from the Universiti Teknologi Malaysia (UTM) in 2009. Subsequently, in August 2012, she received her master degree from UTM in Environmental Engineering. Now, she is a PhD candidate in Advanced Membrane Technology Research Centre at UTM with research interests in dual layer hollow fibre (DLHF) membrane fabrication. Her works focuses on fabrication and application of DLHF on photocatalytic degradation of nonylphenol. Hazlini has published 3 articles and 1 article in international conference. She received bronze award in Industrial Art and Technology Exhibition in 2011 and 2012. Before she pursued her study, she worked as an assistant research officer from September 2012 until January 2014 at Faculty of Civil Engineering, UTM.

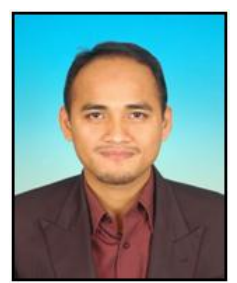

Mohd Hafiz Dzarfan graduated with first class degree of bachelor of science in chemical engineering from Universiti Teknologi Malaysia (UTM) and began his academic career as a tutor at the Department of Gas Engineering in UTM in 2004. Two years later in 2006, he successfully obtained master of engineering (M.Eng) with the publication of one article paper in international journal and two articles in national journal, before was appointed as a lecturer in UTM in the same year. In the end of 2007 , he pursued his PhD study in Imperial College London and had been working on the project of "High Performance Micro-Tubular Solid Oxide Fuel Cell". In this study, he successfully developed a novel, high quality hollow fibre support for an energy conversion device, so-called micro-tubular solid oxide fuel cells (SOFCs), using a more economical and reliable technique, i.e., a phase inversion-based co-extrusion process. During the period of his $\mathrm{PhD}$ study, he managed to publish 11 articles papers in high-reputation journals and 1 article in book chapter. After coming back from $\mathrm{PhD}$, he continues his interest in membrane research by starting a new research area in Malaysia, which is more focused on ceramic membrane for high temperature purpose.

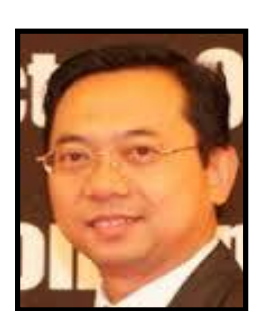

Ahmad Fauzi Ismail holds a BSc in petroleum engineering, MSc in chemical engineering from Universiti Teknologi Malaysia (UTM) and PhD in chemical and process engineering from University of Strathclyde, UK under the Association of Commonwealth Universities Scholarship. He is the founder and head of Advanced Membrane Technology Research Center (AMTEC), UTM Malaysia. Currently he is the dean of Research for Materials and Manufacturing Research Alliance, UTM. He has over 15 years experience in the development of membrane technology for reverse osmosis, nanofiltration, ultrafiltration, membrane contactor and gas separation. The development of nanofibers and carbon nanostructured materials for energy related application is also of special interest. He is the author of over 100 refereed publications. He has also authored 2 books, 7 book chapters and 2 edited books. He has won over 60 awards and one of the outstanding awards is the ASEAN Young Scientist Award in 2001.

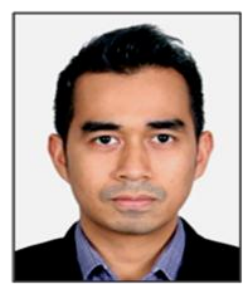

Mohd Hafiz Puteh graduated with B.Eng in chemical engineering and master of engineering in environmental engineering from Universiti Teknologi Malaysia (UTM) in 2004 and 2006 respectively. He started his academic career when he was appointed as a tutor in 2006 in the Department of Environmental Engineering, Faculty of Civil Engineering. Shortly after that, he was granted with a scholarship from Ministry of Higher Education to further his $\mathrm{PhD}$ study in Chemical Engineering at Imperial College London, focusing on biodegradation of nonylphenol Ethoxylates (NPEOs) in a membrane aerated biofilm reactor (MABR). He is now actively involved in 'Research and Innovation' and 'Teaching and Learning' fields.

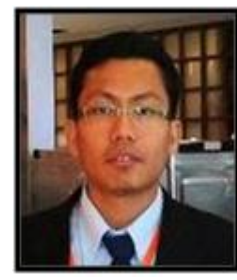

Mukhlis A. Rahman graduated with B.Eng in chemical engineering and master of engineering in environmental engineering from Universiti Teknologi Malaysia (UTM). He started his academic career when he was appointed as a lecturer in 2007 in the Department of Gas Engineering, Faculty of Petroleum Engineering and Renewable Engineering. At the same time, he was joining Advanced Membrane Technology Research Center to participate more on research and innovation field. Shortly after that, he was granted with a scholarship from Ministry of Higher Education to further his $\mathrm{PhD}$ study in Chemical Engineering at Imperial College London, focusing his scope on ceramic membrane for microreactor. He was able to complete his PhD study in 3 years and 8 months before come back to UTM on August 2011 to continue his academic career. Dr. Mukhlis A Rahman has great passion in 'Research and Innovation' fields. He intends to develop ceramic hollow fibre membrane locally to be used in various applications such as gas separation, combustion, catalytic reaction, energy conversion and wastewater treatment. Due to excellent performance during Msc and Phd studies, he received already obtained 9 publications in refereed international journals with $28 \mathrm{CIF}, 5$ working papers in books, 1 patent filling.

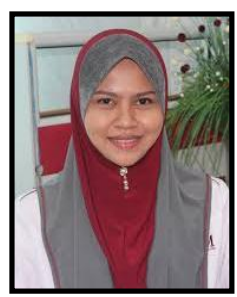

Juhana Jaafar graduated with B.Eng in chemical engineering from Universiti Teknologi Malaysia in 2004. She was then granted with National Science Fellowship under Ministry of Higher Education (MOHE) to pursue her M.Sc. in gas engineering from Universiti Teknologi Malaysia. In 2011, she graduated with a Ph.D. in gas engineering from the same university specializing in advanced membrane manufacturing for energy application. She has started her academic career at UTM in 2007. Currently she is the lecturer of Gas Engineering Department, Faculty of Petroleum and Renewable Energy Engineering. Her professional expertise covers membrane material development for energy application and water and wastewater treatment. During her PhD study, her outstanding outputs in research have received some awards including Gold Medal at the Industrial Art \& Technology Exhibition in 2007 and Gold Medal and Best of the Best at the Malaysian Technology Expo (MTE) in 2008. Her research works were also recognized at the international level when she received the Gold and Double Gold Award at the British Invention Show in 2008. She is now active participating in scientific research and development. 